\title{
Foreign Body Reaction
}

National Cancer Institute

\section{Source}

National Cancer Institute. Foreign Body Reaction. NCI Thesaurus. Code C50444.

A granulomatous inflammatory reaction evoked by the presence of an exogenous

material in the tissues, a characteristic feature of which is the formation of foreign body giant cells. 